\section{Willingness to Pay for Optimal 'Anjou' Pear Quality}

\author{
R. Karina Gallardo ${ }^{1,4}$ \\ School of Economic Sciences and Tree Fruit Research and Extension Center, \\ Washington State University, 1100 North Western Avenue, Wenatchee, WA \\ 98801
}

\begin{abstract}
Eugene Kupferman ${ }^{2}$
Department of Horticulture and Landscape Architecture and Tree Fruit Research and Extension Center, Washington State University, Wenatchee, WA 98801
\end{abstract}

Ann Colonna
Food Innovation Center, Oregon State University, Portland, OR 97209

Additional index words. 'Anjou' pears, postharvest, quality, willingness-to-pay

\begin{abstract}
In light of increasing consumer demand for optimal fresh fruit quality, experience attributes are crucial to ensure repeated purchases and price premiums. Challenges in offering consistent quality throughout the marketing year make 'Anjou' pears an interesting case in which to analyze the effects of experience quality attributes on willingness to pay. We analyzed data from choice experiments conducted along with sensory tests at two different times during the marketing year. Results indicate that individuals are willing to discount between $15.43 \mathrm{cents} / \mathrm{kg}$ to $37.48 \mathrm{cents} / \mathrm{kg}$ for a one-unit increase in pear firmness and pay between 19.84 cents/ $\mathrm{kg}$ to $24.25 \mathrm{cents} / \mathrm{kg}$ for a one-unit increase in soluble solid concentration. This information would help the industry assign priority to the factors likely enhancing the characteristics leading to repeated sales at price premiums. Also, this information is valuable to related sciences because it provides market information for focusing research portfolios on quality characteristics likely to increase pears' commercial viability.
\end{abstract}

Marketing of fresh fruits is evolving as consumers are becoming increasingly demanding of quality. Today's breeders, postharvest scientists, and the industry in general have to pay closer attention to consumers' quality demands to guarantee commercial viability. Nelson (1970) objectively defined quality by describing it in three dimensions: search (or appearance), credence, and experience. In the case of fresh fruits, quality of appearance is important because, in most cases, consumers rely on it to decide whether to buy. Moreover, standards and grades for fresh fruits are typically based on appearance characteristics such as size, color, shape, and external damage. Another quality dimension

Received for publication 15 Oct. 2010. Accepted for publication 14 Dec. 2010.

We gratefully acknowledge Hayley Chouinard and Jill McCluskey from the School of Economic Sciences at Washington State University for their helpful comments that improved the manuscript. We also thank Chris Sater, former Associate in Research at the Tree Fruit Research and Extension Center at Washington State University, for her valuable help toward the completion of the manuscript. Finally, we thank the Pear Bureau Northwest for funding this research.

${ }^{1}$ Assistant Scientist and Extension Specialist.

${ }^{2}$ Postharvest Specialist.

${ }^{3}$ Sensory Program Manager.

${ }^{4}$ To whom reprint requests should be addressed; e-mail karina_gallardo@wsu.edu. includes credence attributes, which require a third party verification because it is not possible to confirm their presence by simple inspection or after tasting the product. Examples of credence attributes include organic, sustainable, functional, locally grown, and so on. The third quality dimension is experience, which relies on individuals' overall sensory perceptions, because attributes are difficult to observe by visual inspection alone. It is believed that experience attributes are determinant in assuring repeated food sales, because it is the quality of similar products bought in the past (that is, one's previous experiences) that serve as an indicator of present and future quality (Shapiro, 1983). Also, several studies have demonstrated that optimal quality characteristics, as defined by consumers, are associated with willingness to pay premiums for fruit (Carew, 2000; McCluskey et al., 2007; Quagrainie et al., 2003).

This article investigates the effects of eating quality characteristics on the value consumers place on fresh 'Anjou' pear quality. This is an important research question for the pear industry because the potential of increasing commercial viability is dependent on the industry's capability of supplying consistent and optimal quality. Hence, information on consumers' willingness to pay for quality attributes would help assign priority to the factors likely enhancing the characteristics leading to increased commercial viability. This information is also valuable for scientists such as fruit breeders and postharvest researchers to help them focus research efforts on quality attributes likely to be responsible for making a product successful in the marketplace. To accomplish the study's objectives, we used data from two sensory tests in which pears under different post-harvest treatments were analyzed. Treatments consisted of applying varying amounts of ethylene, a naturally occurring hormone, to pears at two different times during the marketing season (December and March).

Why 'Anjou' pears? Besides being one of the most popular pear varieties grown in the Pacific Northwest with an average production of 2.2 million metric tons per year (Washington Growers Clearing House, 2009), 'Anjou' pears present an interesting case in which to analyze the interactions between experience quality attributes and willingness to pay. First, the pear industry faces no small challenges to obtain and deliver consistent quality to consumers. Such challenges start at the orchard level and remain throughout the marketing chain (Kupferman et al., 2009). At the orchard, fruit firmness varies by location within the tree, harvest date, and orchard elevation. Challenges from the retail and distribution network are presented by retailers who prefer hard pears because there is less loss to marking or decay; however, this comes at the expense of having pears less appealing to consumers who want ready-toeat fruit. Second, there is the challenge of consistently supplying pears throughout the entire marketing year. Winter pears need to be put in cold storage $\left(-1^{\circ} \mathrm{C}\right)$ for 2 to 8 weeks after harvest to induce ripening and prevent putting hard fruit in the market (Chen et al., 1996; Kappel et al., 1995; Kupferman, 1994; Shang Ma et al., 2000). This chilling period delays the entry into the market and likely deters sales (Schotzko et al., 2001; Shang Ma et al., 2000). A long-studied alternative is to induce and control ripening by using ethylene gas (Chen et al., 1996; Shang Ma et al., 2000).

Despite the strong link between marketing decisions and final product quality of 'Anjou' pears, little empirical work on consumers' values for pear eating attributes has been conducted. To our knowledge, only the studies conducted by Combris et al. (2007) and Zhang et al. (2010) elicited consumers' economic values for pear eating quality. Combris et al. (2007) conducted experimental auctions along with sensory tests and found that consumers were willing to pay premiums ranging from 8 cents/lb for a oneunit increase in soluble solids concentration (SSC). Zhang et al. (2010) used results from a sensory taste with a contingent valuation questionnaire to measure consumers' willingness to pay for pear eating quality. They found that on average, consumers were willing to pay 5.7 cents, 3.7 cents, and 8.5 cents more for a one-unit increase in the liking rate for pears sweetness, juiciness, and firmness, respectively. (The liking rate was measured 
on a 9-point hedonic scale with 1 being "extremely dislike" and 9 "extremely like.") Because liking rates are mostly subjective and highly variable across individuals, in this study, to measure the effects of quality characteristics on willingness to pay, we use physiochemical measures for firmness and SSC.

\section{Materials and Methods}

Sensory tests. Sensory tests were conducted in Dec. 2008 and Mar. 2009 at the Food Innovation Center, Oregon State University in Portland, OR. Participants for each test were recruited using an online screening questionnaire sent to $\approx 5000$ consumers in the Portland metropolitan area. A between-subject design was used, because different consumers were recruited and randomly assigned to trials in December and March. In each, a planned sample size of 120 consumers [The standard sample size for a central location test of over 100 consumers was used and 20 extra individuals were recruited for each test to cover for last minute cancellations by participants (Meilgaard et al., 1999).] was selected to participate in the sensory test. Because our objective was to assess how pear eaters would define optimal quality, we based our sampling on the sociodemographic criteria given by the Pear Bureau Northwest for pear consumers $[75 \%$ to $80 \%$ female, white, annual household income above $\$ 25,000$ / year, 35 to 65 years of age, and post-secondary education (Moffitt, 2002)]. Compared with the city of Portland population (U.S. Census Bureau, 2000), our two samples of panelists over-represented the groups 45 to 54 and 55 to 64 years old, female, white, advanced college degree, and income range $\$ 75,000$ to $\$ 99,000$ (Table 1 ).

Before being served, individuals were given a brief set of instructions on how to complete the test. Once in the sensory testing booths, panelists were presented with pear samples that were labeled with random threedigit codes representing different postharvest treatments. Just before being served, each pear was tested for firmness using a Fruit Texture Analyzer penetrometer (Güss Manufacturing, Stand, South Africa). One half of the fruit used for the firmness testing was juiced to determine SSC on each pear; the other half was served to panelists.

Postharvest treatments. Several postharvest treatments were studied to measure their effects on pears' final quality. The treatments used were selected based on the maturity of the fruit at the time of the experiment. In general, the longer pears are held in storage, the less time they need in a conditioning environment to ripen properly. Pears used in December were kept in controlled atmosphere (CA) storage for $70 \mathrm{~d}$. Twenty-four $\mathrm{h}$ before conditioning, fruit was placed in a warm room $\left(23^{\circ} \mathrm{C}\right)$. Conditioning was done at $23{ }^{\circ} \mathrm{C}$ in shroud-covered box pallets using ethylene release canisters (ERCs) (Balchem Corporation, New Hampton, NY) and at least $50 \mathrm{ppm}$ ethylene after $6 \mathrm{~h}$. One of four

Table 1. Comparison between sensory taste participants and Portland demographics.

\begin{tabular}{|c|c|c|c|}
\hline Demographics & $\begin{array}{c}\text { Dec. } 2008 \\
(\mathrm{~N}=111 ; \%)\end{array}$ & $\begin{array}{c}\text { Mar. 2009 } \\
(\mathrm{N}=120 ; \%)\end{array}$ & $\begin{array}{c}\text { US Census Portland } \\
\text { Population }=529,121(\%)\end{array}$ \\
\hline \multicolumn{4}{|l|}{ Age (years) } \\
\hline Younger than 24 & 0 & 4.2 & 31.4 \\
\hline $25-34$ & 32.4 & 22.5 & 18.3 \\
\hline $35-44$ & 18.9 & 22.5 & 16.4 \\
\hline $45-54$ & 21.6 & 19.2 & 14.8 \\
\hline $55-64$ & 21.6 & 25.0 & 7.6 \\
\hline Older than 65 & 5.4 & 6.7 & 11.5 \\
\hline \multicolumn{4}{|l|}{ Gender } \\
\hline Male & 27.9 & 30.8 & 49.4 \\
\hline Female & 72.1 & 69.2 & 50.6 \\
\hline \multicolumn{4}{|l|}{ Ethnicity } \\
\hline American Indian, Alaska Native & 1.8 & 0 & 1.1 \\
\hline Asian, Asian American & 4.5 & 4.2 & 6.3 \\
\hline Black, African American & 1.8 & 0 & 6.6 \\
\hline Hispanic, Latin American & 1.8 & 3.3 & 6.8 \\
\hline White & 87.4 & 90.0 & 77.9 \\
\hline Other & 1.8 & 0.8 & 1.3 \\
\hline Decline to respond & 0.9 & 1.7 & \\
\hline \multicolumn{4}{|l|}{ Education } \\
\hline High school graduate & 5.4 & 3.3 & 22.2 \\
\hline 2-year college or technical degree & 25.2 & 25.0 & 30.8 \\
\hline 4-year college & 43.2 & 44.2 & 21.3 \\
\hline Advanced college degree & 26.1 & 27.5 & 11.4 \\
\hline \multicolumn{4}{|l|}{ Income } \\
\hline Less than $\$ 25,000 /$ year & 14.4 & 4.2 & 29.5 \\
\hline$\$ 25,000-\$ 34,999 /$ year & 8.1 & 26.7 & 13.9 \\
\hline$\$ 35,000-49,999 /$ year & 21.6 & 24.2 & 17.3 \\
\hline$\$ 50,000-\$ 74,999 /$ year & 27.0 & 14.2 & 19.9 \\
\hline$\$ 75,000-\$ 99,999 /$ year & 17.1 & 19.2 & 9.2 \\
\hline$\$ 100,000 /$ year or more & 11.7 & 11.7 & 10.3 \\
\hline
\end{tabular}

treatments was applied to each test group: 1,2 , or $4 \mathrm{~d}$ with ethylene or no ethylene exposure. After treatment, all fruit was returned to cold storage $\left(-1{ }^{\circ} \mathrm{C}\right)$ to simulate transit to retail market, and $2 \mathrm{~d}$ before consumer evaluation, all fruit was removed from cold storage and held at $21^{\circ} \mathrm{C}$ until testing.

Pears used in March were kept in CA for $169 \mathrm{~d}$. Twenty-four $\mathrm{h}$ before being treated, fruit was placed in a warm room at $22{ }^{\circ} \mathrm{C}$. Like with the trial in December, treatment was done in shroud-covered box pallets at $22{ }^{\circ} \mathrm{C}$ using ERCs and reached at least $50 \mathrm{ppm}$ ethylene after $6 \mathrm{~h}$. Five treatments were applied: $2 \mathrm{~d}$ in ethylene, $1 \mathrm{~d}$ in ethylene, $1 \mathrm{~d}$ in ethylene followed by $1 \mathrm{~d}$ in warm air, $2 \mathrm{~d}$ in warm air, and no treatment. After being treated, fruit was returned to cold storage $(-1$ ${ }^{\circ} \mathrm{C}$ ) for 7 or $8 \mathrm{~d}$ to simulate transit to a retail market. Three $\mathrm{d}$ before consumer evaluation, all fruit was removed from cold storage and held at $22{ }^{\circ} \mathrm{C}$ until testing.

Questionnaire. After tasting each sample, individuals were asked to rate overall liking, pear flavor, sweetness, juiciness, firmness, and texture liking using a 9-point hedonic scale with 1 at "dislike extremely" and 9 at "like extremely." Also, individuals were asked about their purchasing habits such as price usually paid for pears, frequency of consumption, planned grocery shopping, and attitudes toward locally grown and organic fresh produce as well as demographic questions. The final step was a set of choice experiment questions to elicit the willingness to pay.

Choice experiment. Participants were asked to answer hypothetical purchasing questions. In each question, individuals were asked to choose the option describing the pear sample they preferred out of five (December) or six (March) options. A "none" option was also included. See Figure 1 for an example of the choice question. Each option was randomly assigned prices obtained from grocery stores in Portland 1 week before each experiment. In the December trial, prices ranged from $\$ 1.49 / \mathrm{lb}(\$ 3.28 / \mathrm{kg})$ to $\$ 1.99 / \mathrm{lb}$ $(\$ 4.39 / \mathrm{kg})$ in $\$ 0.10$ or $\$ 0.20$ increments. A fractional factorial design was used to randomize price and alternative matching. The design yielded 32 questions that were divided into four groups; thus, each respondent answered eight questions. For the trial conducted in March, prices ranged from \$1.39/lb $(\$ 3.06 / \mathrm{kg})$ to $\$ 2.19 / \mathrm{lb}(\$ 4.83 / \mathrm{kg})$ in $\$ 0.20$ increments. The fractional factorial design yielded 25 questions that were divided randomly into two groups of 12 and 13 questions each.

Model specification. We assume a random utility model in which the $i^{\text {th }}$ individual's utility from choosing treatment $j$ is given by:

$$
U_{i j}=V_{i j}+\varepsilon_{i j}
$$

where $V_{i j}$ is the deterministic portion of the utility and $\varepsilon_{i j}$ is the identically independent distributed stochastic error component. In this study, $V_{i j}$ is represented by:

$$
\begin{aligned}
V_{i j}= & \lambda_{1 i j}+\lambda_{2} \text { Firmness }_{i j} \\
& +\lambda_{3} S_{S C_{i j}}+\beta \text { Pr } i c e_{i j}
\end{aligned}
$$

where $\lambda_{1 i j}$ is the alternative specific constant denoting the utility derived for choosing pears under treatment $j$ relative to not choosing any 


\begin{tabular}{l|l}
\hline \multicolumn{2}{|c}{ SCenario 1 } \\
PEAR & $\begin{array}{l}\text { I WOULD CHOOSE } \\
\text { SAMPLE }\end{array}$ \\
& $\begin{array}{l}\text { CHECK “ } \checkmark \text { " THE BOX } \\
\text { THAT BEST MATCHES } \\
\text { YOUR } \\
\text { PREFERENCE }\end{array}$ \\
\hline $\mathbf{1 2 3}$ & $\$ 1.79 / \mathrm{lb}$ \\
\hline $\mathbf{2 4 5}$ & $\$ 1.79 / \mathrm{lb}$ \\
\hline $\mathbf{3 4 8}$ & $\$ 1.59 / \mathrm{lb}$ \\
\hline $\mathbf{4 8 9}$ & $\$ 2.19 / \mathrm{lb}$ \\
\hline $\mathbf{5 6 7}$ & $\$ 1.79 / \mathrm{lb}$ \\
\hline NONE & \\
\hline
\end{tabular}

Fig. 1. Example of choice experiment question.

option; Firmness and SSC are the instrumental measurements for firmness and SSC as measured for treatment $j$; Price is the price of treatment $j$; and $\lambda_{2}, \lambda_{3}$, and $\beta$ are the marginal utility of firmness, SSC, and price, respectively.

To estimate coefficients in the model, we used the mixed logit specification. This allows coefficients in Eq. [2] to vary across individuals. In this study, coefficients are assumed to follow a normal distribution, depicted by:

$$
\lambda_{i j}=\bar{\lambda}_{j}+\sigma_{j} u_{i j}
$$

where $\bar{\lambda}_{j}$ is the population mean of coefficients, $\sigma_{j}$ denotes the SD around the population mean, and $u_{i j}$ is the error term following a standard normal distribution. The coefficient for price is assumed to be invariant across individuals, because lower-priced samples have a higher probability of being chosen than higher-priced ones, all else remaining constant. Train (2003) showed that the probability that consumer $i$ chooses treatment $j$ is:

$$
P_{i}=\int \frac{\exp \left(V_{i j}\right)}{\sum_{j \in C_{i}} \exp \left(V_{i k}\right)} f\left(\lambda_{i}\right) d \lambda_{i}
$$

where $f\left(\lambda_{i}\right)$ is the probability distribution of coefficients $\lambda_{i}$. Because Eq. [4] does not have a close form, coefficients are calculated by approximation using simulated maximum likelihood.

\section{Results and Discussion}

A total of 112 and 120 completed questionnaires were used from the trials in Dec. 2008 and Mar. 2009, respectively. For the December trial, individuals' most preferred sample was the pear under treatment 4-days ethylene with firmness $11.08 \mathrm{~N}$ and SSC $15.16 \%$ (Table 2). As for the March trial, there were two most preferred samples: treatments 1-day ethylene + 1-day warm air and 2-days warm air with firmness $13.65 \mathrm{~N}$ and $13.97 \mathrm{~N}$ and SSC $13.87 \%$ and $14.02 \%$, respectively. For both trials, most preferred sample firmness $(11.08 \mathrm{~N}$ to $13.97 \mathrm{~N})$ was lower than those in Kappel et al. (1995), who found that optimum firmness ranged from 18 to $22 \mathrm{~N}$. Differences in preference for firmness show that preference across consumer groups is highly variable and dependent on individuals' particular tastes and preferences. Most preferred samples' SSC were similar in both studies: no less than 14\%. In summary, for the particular group of individuals participating in this study, optimal pears (the ones rated as most liked) should exhibit firmness levels between 11.08 and $13.97 \mathrm{~N}$ and SSC no less than $14 \%$.

Estimates for the mixed logit coefficients are presented in Table 3 . In both data sets (December and March), all mean value estimates are statistically significant at the 5\% level. Coefficients indicate individuals' preference for pears is positively correlated with SSC and negatively correlated with firmness and price. In relation to SD coefficients, for the December data set, only the SD of 2-day ethylene and firmness turned out to be statistically significant at the $5 \%$ level. This indicates that preferences were mostly invariant across respondents. However, for the March data set, almost all SD estimates were statistically significant (except 2-days warm air and firmness), showing that preferences varied across respondents. Differences across data sets prove that heterogeneity across individuals' preferences is subject to the specific characteristics of pears in each trial.

Willingness to pay for pears under each treatment and for a one-unit increase in firmness and soluble solids is presented in Table 4. To obtain this statistic, we divided the marginal utility of pears under each treatment, firmness, and SSC by the marginal utility of price. The resulting quotient was multiplied by negative one $(-1)$. We also report the $95 \%$ confidence intervals for willingness-to-pay estimates. Confidence intervals were obtained through parametric bootstrapping following the Krinsky and Robb procedure (Krinsky and Robb, 1986).

Results indicated that for the December trial, individuals are willing to discount 15.43 cents/kg for a one-unit increase in firmness and pay 19.84 cents $/ \mathrm{kg}$ for a one-unit increase in SSC. As for the March trial, individuals indicated a discount of 37.48 cents $/ \mathrm{kg}$ for a one-unit increase in firmness and premium of 24.25 cents $/ \mathrm{kg}$ for a one-unit increase in SSC. Willingness-to-pay results are reasonably close to findings in Combris et al. (2007) who estimated 17.64 cents $/ \mathrm{kg}$ for a one-unit increase in SSC. Differences in willingnessto-pay estimates across trials might be explained by the particular taste and preferences of each consumer group.

In relation to willingness-to-pay for pears under each treatment, we found that even in December, when pears have been kept in cold storage for $70 \mathrm{~d}$ (more than the required period to start ripening), ethylene has a positive effect on quality characteristics. Consumers were willing to pay a premium of 44 cents $/ \mathrm{kg}$ for pears under 4-d ethylene treatment when compared with pears not receiving any treatment. However, preference for samples under 2-d and 1-d ethylene treatment was not greater than for the sample not receiving a treatment. Similarly, in March, when pears have completed the chilling requirement by far, treatments $2-d$ warm air and 1-d ethylene + 1-d warm air appear to enhance quality characteristics most preferred by consumers. The preference is reflected in the stated premiums of 39 cents $/ \mathrm{kg}$ more compared with the sample not receiving any treatment. These results are important cues for pear packing houses who are considering ethylene as a postharvest treatment to enhance pear eating quality.

Relevant to the implications for the industry are the ethylene treatment costs. Costs are highly variable and dependant on the size of operations. In general, costs for treating pears with ethylene include a storage room (or trailer rental), an ethylene dispenser and ethylene concentrate, and energy. Zhang et al. (2010) estimated that the cost of ethylene

\begin{tabular}{|c|c|c|c|c|c|c|c|c|}
\hline \multirow[b]{2}{*}{ Treatment } & \multicolumn{6}{|c|}{ Mean values liking scale $(1=$ dislike extremely, $9=$ like extremely) } & \multicolumn{2}{|c|}{ Instrumental measure } \\
\hline & Overall liking & Flavor & Sweetness & Juiciness & Firmness & Texture & Firmness (N) & Soluble solids ( $\left.{ }^{\circ} \mathrm{Brix}\right)$ \\
\hline \multicolumn{9}{|l|}{ Dec. 2008} \\
\hline 1-d ethylene & $5.63 c^{z}$ & $5.76 \mathrm{c}$ & $4.30 \mathrm{~d}$ & $3.66 \mathrm{~d}$ & $5.66 \mathrm{~b}$ & $5.31 \mathrm{c}$ & $29.56 \mathrm{c}$ & $14.51 \mathrm{c}$ \\
\hline 2-d ethylene & $6.21 \mathrm{bc}$ & $6.09 \mathrm{bc}$ & $5.15 \mathrm{c}$ & $5.05 \mathrm{c}$ & $6.27 \mathrm{ab}$ & $6.12 b$ & $20.03 \mathrm{~b}$ & $14.68 \mathrm{bc}$ \\
\hline 4-d ethylene & $7.49 \mathrm{a}$ & $7.49 \mathrm{a}$ & $6.85 \mathrm{a}$ & $7.56 \mathrm{a}$ & $6.53 \mathrm{a}$ & $6.83 \mathrm{a}$ & $11.08 \mathrm{a}$ & $15.16 \mathrm{a}$ \\
\hline No treatment & $6.42 \mathrm{~b}$ & $6.49 \mathrm{~b}$ & $5.96 \mathrm{~b}$ & $6.39 \mathrm{~b}$ & $5.83 \mathrm{~b}$ & $5.82 \mathrm{bc}$ & $12.31 \mathrm{a}$ & $14.81 \mathrm{~b}$ \\
\hline \multicolumn{9}{|l|}{ Mar. 2009} \\
\hline 1-d warm air & $6.21 \mathrm{a}$ & $6.00 \mathrm{abc}$ & $5.01 \mathrm{~b}$ & $5.64 \mathrm{~b}$ & $6.30 \mathrm{~b}$ & $6.09 \mathrm{ab}$ & $17.58 \mathrm{a}$ & $13.86 \mathrm{~b}$ \\
\hline 1-d ethylene & $6.10 \mathrm{a}$ & $5.81 \mathrm{c}$ & $5.20 \mathrm{~b}$ & $5.65 \mathrm{~b}$ & $6.16 \mathrm{~b}$ & $5.78 \mathrm{~b}$ & $17.50 \mathrm{a}$ & $13.80 \mathrm{~b}$ \\
\hline 2-d warm air & $6.59 \mathrm{a}$ & $6.57 \mathrm{a}$ & $6.01 \mathrm{a}$ & $6.83 \mathrm{a}$ & $6.61 \mathrm{a}$ & $6.67 \mathrm{a}$ & $13.97 \mathrm{a}$ & $14.02 \mathrm{a}$ \\
\hline 1-d ethylene +1 -d warm air & $6.61 \mathrm{a}$ & $6.41 \mathrm{ab}$ & $6.06 \mathrm{a}$ & $6.74 \mathrm{a}$ & $6.67 \mathrm{a}$ & $6.59 \mathrm{a}$ & $13.65 \mathrm{a}$ & $13.87 \mathrm{a}$ \\
\hline No treatment & $6.02 \mathrm{a}$ & $5.90 \mathrm{bc}$ & $5.28 \mathrm{~b}$ & $5.78 \mathrm{~b}$ & $6.20 \mathrm{a}$ & $5.78 \mathrm{~b}$ & $15.05 \mathrm{a}$ & $13.75 \mathrm{~b}$ \\
\hline
\end{tabular}

Table 2. Summary statistics of ranking and instrumental measures for each sample treatment.

${ }^{\mathrm{z} L e t t e r s ~ s h o u l d ~ b e ~ r e a d ~ b y ~ r o w ~ f o r ~ e a c h ~ v a r i a b l e . ~ D i f f e r e n t ~ l e t t e r s ~ d e n o t e ~ s t a t i s t i c a l l y ~ s i g n i f i c a n t ~ d i f f e r e n c e s ; ~ s a m e ~ l e t t e r s ~ d e n o t e ~ n o t ~ s t a t i s t i c a l l y ~ s i g n i f i c a n t ~}$ differences. 
Table 3. Parameter estimates for modeling consumers' preferences for 'Anjou' pear quality attributes under different conditioning protocols-December and March experiments.

\begin{tabular}{|c|c|c|c|c|}
\hline \multirow[b]{3}{*}{ Variables } & \multicolumn{2}{|c|}{ Dec. 2008} & \multicolumn{2}{|c|}{ Mar. 2009} \\
\hline & \multicolumn{2}{|c|}{ Parameter estimate } & \multicolumn{2}{|c|}{ Parameter estimate } \\
\hline & Mean & $\mathrm{SD}$ & Mean & SD \\
\hline \multicolumn{5}{|l|}{ Dec. 2008} \\
\hline Price & $\begin{array}{c}-4.23^{* z} \\
(0.65)^{y}\end{array}$ & - & - & - \\
\hline 1-d ethylene & $\begin{array}{c}6.53 * \\
(2.21)\end{array}$ & $\begin{array}{c}0.10 \\
(2.63)\end{array}$ & - & - \\
\hline 2-d ethylene & $\begin{array}{c}6.91 * \\
(2.21)\end{array}$ & $\begin{array}{c}1.65^{*} \\
(0.90)\end{array}$ & - & - \\
\hline 4-d ethylene & $\begin{array}{c}8.05^{*} \\
(2.29)\end{array}$ & $\begin{array}{c}0.08 \\
(1.92)\end{array}$ & - & - \\
\hline No treatment & $\begin{array}{l}7.21 \% \\
(2.23)\end{array}$ & $\begin{array}{c}-0.18 \\
(1.99)\end{array}$ & - & - \\
\hline Firmness & $\begin{array}{c}-0.28^{*} \\
(0.09)\end{array}$ & $\begin{array}{c}-0.67^{*} \\
(0.14)\end{array}$ & - & - \\
\hline Soluble solids & $\begin{array}{c}0.36^{*} \\
(0.08)\end{array}$ & $\begin{array}{c}-0.16 \\
(0.10)\end{array}$ & - & - \\
\hline \multicolumn{5}{|l|}{ Mar. 2009} \\
\hline Price & - & - & $\begin{array}{c}-7.27 * \\
(2.54)\end{array}$ & - \\
\hline 1-d warm air & 一 & - & $\begin{array}{c}16.55^{*} \\
(6.27)\end{array}$ & $\begin{array}{c}-4.26^{*} \\
(1.75)\end{array}$ \\
\hline 1-d ethylene & - & - & $\begin{array}{c}17.05^{*} \\
(6.40)\end{array}$ & $\begin{array}{c}2.50^{*} \\
(1.25)\end{array}$ \\
\hline 2-d warm air & - & - & $\begin{array}{c}17.76^{*} \\
(6.67)\end{array}$ & $\begin{array}{c}1.34 \\
(0.95)\end{array}$ \\
\hline 1 -d ethylene +1 -d warm air & - & - & $\begin{array}{c}17.75^{*} \\
(6.65)\end{array}$ & $\begin{array}{c}2.76^{*} \\
(1.25)\end{array}$ \\
\hline No treatment & - & - & $\begin{array}{l}16.42 * \\
(6.23)\end{array}$ & $\begin{array}{c}-2.77^{*} \\
(1.28)\end{array}$ \\
\hline Firmness & - & - & $\begin{array}{c}-1.20^{*} \\
(0.44)\end{array}$ & $\begin{array}{c}0.20 \\
(0.38)\end{array}$ \\
\hline Soluble solids & - & - & $\begin{array}{c}0.83^{*} \\
(0.31)\end{array}$ & $\begin{array}{c}-0.80^{*} \\
(0.31)\end{array}$ \\
\hline Number of observations & 808.00 & 1473.00 & & \\
\hline Log likelihood & -1010.00 & -2140.00 & & \\
\hline Likelihood ratio & 581.62 & 1248.20 & & \\
\hline
\end{tabular}

${ }^{\mathrm{z}}$ Numbers in parentheses are SES.

${ }^{\mathrm{y}}$ One asterisk indicates statistically significant at the $5 \%$ level.

Table 4. Willingness to pay for pear treatments and quality characteristics and market share for pears under each treatment.

\begin{tabular}{lrrr}
\hline & \multicolumn{2}{c}{ Willingness to pay $(\$ / \mathrm{kg})$} & \\
\cline { 2 - 3 } Variable & Mean & 95\% Confidence intervals & Market share (\%) \\
\hline Dec. 2008 & 3.42 & $1.74-5.05$ & 3.56 \\
1-d ethylene & 3.59 & $1.92-5.38$ & 9.92 \\
2-d ethylene & 4.19 & $2.49-5.78$ & 63.98 \\
4-d ethylene & 3.75 & $1.98-5.40$ & 22.55 \\
No treatment & -0.15 & $-0.22-0.07$ & \\
Firmness & 0.20 & $0.13-2.47$ & \\
Soluble solids & & & \\
Mar. 2009 & 5.03 & $3.24-7.01$ & 6.16 \\
1-d warm air & 5.18 & $3.40-7.19$ & 42.18 \\
1-d ethylene & 5.38 & $3.57-7.32$ & 40.43 \\
2-d warm air & 5.38 & $3.57-7.32$ & 6.58 \\
1-d ethylene + 1-d warm air & 4.98 & $3.17-6.95$ & \\
No treatment & -0.37 & $-0.44-0.29$ & \\
Firmness & 0.24 & $0.18-0.33$ & \\
Soluble solids & &
\end{tabular}

treatment to be 0.4 cents $/ \mathrm{lb}(0.88$ cents $/ \mathrm{kg})$. Based on this, the premiums that can be obtained from ethylene treatments $(39.68$ cents to 44.09 cents $/ \mathrm{kg}$ ) are greater than this cost.

Market share estimation. Market share is a useful statistic for the industry, because it gives an indication of the potential share pears (with similar characteristics as described in this study) would have if they were in the market. In other words, it indicates the probability that individuals would choose pears conditioned under one particular treatment, if they had as all available alternatives pears with characteristics resulting from the treatments described in this study, at a fixed price level [ $\$ 1.50 / \mathrm{lb}(\$ 3.31 / \mathrm{kg})]$.

Results, presented in Table 4, indicate that for the December trial, pears under treatment 4-days ethylene will have a $64 \%$ market share relative to the rest of the samples. In contrast, for the March trial, market share for pears under treatments 2-days warm air and 1-day ethylene + 1-day warm air will total $82 \%$ relative to the other samples tasted. Market share estimates are an important piece of information that will give pear agribusiness managers a solid idea of the potential sales pears under ethylene treatment might absorb compared with pears not receiving the treatment.

Validation of results. Because results from stated choice experiments are typically looked on suspiciously because of the potential biases induced by the hypothetical nature of choice questions, laboratory setting, and lack of monetary incentives, we conducted a hold-out sample prediction test to measure the reliability of our results. The test followed the method used by Haener et al. (2001) First, each data set (December and March) was randomly divided into an estimation sample and a hold-out sample. We estimated coefficients for the estimation sample. To ensure reliability, we replicated this procedure 24 times for the December data set and 27 times for the March data set. (The number of replications is related to the number of observations in each data set.)

The prediction success for each replication was measured in terms of the percentage of correctly predicted choices. Results indicate that for the December data set, the model correctly predicted the choices $30.7 \%$ of the time and for the March data set 46.8\% of the time. A model of pure chance would correctly predict the outcomes $20 \%$ of the time for December and $16.7 \%$ for March (note that there were five options in December and six in March). This is not to say that the methodology used guarantees a perfect forecast of consumers' preferences; nonetheless, results from the validation test support the confidence placed in this study's findings.

\section{Conclusions}

Marketing of fresh fruits is evolving toward relying more on consumers, who are becoming increasingly demanding of optimal quality. In such a context, scientists and industry are in search of methods that will ensure a consistent supply of optimal quality. An important piece of information is how consumers would value this quality.

This study investigated how pear consumers in Portland value pear quality characteristics resulting from different postharvest treatments applied two times during the marketing season (December and March). We found that consumers are willing to discount 15.43 cents $/ \mathrm{kg}$ to 37.48 cents $/ \mathrm{kg}$ for a one-unit increase in 'Anjou' pear firmness and are willing to pay 19.84 cents $/ \mathrm{kg}$ to 24.25 cents/ $\mathrm{kg}$ for a one-unit increase in SSC.

Implications of this study emphasize the value of placing optimal quality pears in the market. Also, we show evidence that such quality could be achieved through a postharvest treatment consisting of ethylene application, yet standardization of ethylene application is needed to ensure that the resulting quality 
is supplied in a consistent fashion. As such, challenges remain and ongoing post-harvest research is being conducted to assess the treatments aimed at ensuring a consistent optimal quality supply while simultaneously reducing collateral manipulation costs such as the risk of bruising or general damage during transit or storage.

\section{Literature Cited}

Carew, R. 2000. A hedonic analysis of apple prices and product quality characteristics in British Columbia. Can. J. Agr. Econ. 48:241-257.

Chen, P.M., S.R. Drake, D.M. Varga, and L. Puig. 1996. Precondition of D'Anjou pears for early marketing by ethylene treatment. J. Food Qual. 19:375-390.

Combris, P., A. Seabra Pinto, A. Fragata, and E. Giraud-Heraud. 2007. Does taste beat food safety? Evidence from the 'Pera Rocha' case in Portugal. Presented at the 105th seminar of the European Association of Agricultural Economists, Bologna, Italy, 8-10 Mar.

Haener, M., P. Boxall, and W. Adamowicz. 2001. Modeling recreation site choice: Do hypothetical choices reflect actual behavior? Amer. J. Agr. Econ. 83:629-642.
Kappel, F., R. Fisher-Fleming, and E. Hogue. 1995. Ideal pear sensory attributes and fruit characteristics. HortScience 30:988993.

Krinsky, I. and A.L. Robb. 1986. On approximating the statistical properties of elasticities. Rev. Econ. Stat. 64:715-719.

Kupferman, E. 1994. Anjou pear quality: Fruit quality. Tree Fruit Postharvest J. 5:3-10.

Kupferman, E., R.K. Gallardo, C. Sater, and A. Colonna. 2009. Conditioning Anjou pears to meet consumer quality demands. Invited paper presented at Postharvest Pacifica meetings, Napier, New Zealand, 15-19 Nov.

McCluskey, J., R. Mittelhammer, A. Marin, and K. Wright. 2007. Effect of quality characteristics on consumers' willingness to pay for gala apples. Can. J. Agr. Econ. 55:217-231.

Meilgaard, M., G. Civille, and B. Carr. 1999. Sensory evaluation techniques. 3rd Ed. CRC Press, Boca Raton, FL.

Moffitt, K. 2002. Conditioned fruit: Is it what consumers are looking for? Presented at the Washington Tree Fruit Postharvest Conference, Yakima, WA, 12-13 Mar.

Nelson, P. 1970. Information and consumer behavior. J. Polit. Econ. 78:311-329.

Quagrainie, K.K., J.J. McCluskey, and M.L. Loureiro. 2003. A latent structure approach to measuring reputation. South. Econ. J. 67: 966-977.

Shang Ma, S., P.M. Chen, and D.M. Varga. 2000. Ethylene capsule promotes early ripening of 'D'Anjou' pears packed in modified atmosphere bags. J. Food Qual. 23:245-259.

Shapiro, C. 1983. Premiums for high quality products as returns to reputation. Q. J. Econ. 98:659-680.

Schotzko, T., R.C. Mittelhammer, and P. Gutman. 2001. Effect of size and grade on profitability of marketing D'Anjou pears. Final Report to the PNW Pear Bureau, Portland, Oregon. 20 May 2010. <http://www.agribusinessmgmt.wsu.edu/agbusresearch/docs/pear/ effectsizegradeprofitabilitypears.pdf $>$.

Train, K.E. 2003. Discrete choice methods with simulation. Cambridge University Press, Cambridge, UK.

U.S. Census Bureau. 2000. Portland city demographics. 8 Mar. 2010. <http://quickfacts.census. gov/qfd/states/41/4159000.html $>$.

Washington Growers Clearing House. Five-year Northwest pear production. 17 July 2009. $<\mathrm{http}: / / \mathrm{www}$.waclearinghouse.org $>$.

Zhang, H., R.K. Gallardo, J.J. McCluskey, and E. Kupferman. 2010. Consumers' willingness to pay for treatment induced quality attributes in Anjou pears. J. Agr. Res. Econ. 35:105-117. 